\title{
Spine Myeloid Sarcoma: A Case Series with Review of Literature
}

\author{
Kajal Shah ${ }^{1}$ Harsha Panchal ${ }^{2} \quad$ Apurva Patel $^{2}$ \\ ${ }^{1}$ Department of Medical Oncology, Gujarat Cancer Research \\ Institute, Ahmedabad, Gujrat, India \\ 2Medical Oncology, Gujarat Cancer Research Institute, Ahmedabad, \\ Gujrat, India

\begin{abstract}
Address for correspondence Kajal Shah, Assistant Professor Department of Medical Oncology, Gujarat Cancer Research Institute, Ahmedabad, Gujrat, 380016,,India
\end{abstract} \\ (e-mail: kajal.oncology@gmail.com).
}

\section{South Asian J Cancer 2021;10:251-254.}

\author{
Abstract \\ Keywords \\ - acute myeloid \\ leukemia \\ - chronic myeloid \\ leukemia \\ - granulocytic sarcoma \\ - myelodysplastic \\ syndrome \\ - myeloid sarcoma
}

\begin{abstract}
Myeloid sarcoma (MS) is a malignant extramedullary tumor consisting of immature cells of myeloid origin. It may precede, present concurrently or follow acute myeloid leukemia (AML) in de novo case or may also be present and might be the only manifestation of recurrent AML, myelodysplastic syndrome, or chronic myeloid leukemia. It frequently involves skin, orbit, bone, periosteum, lymph nodes, and gastrointestinal tract, soft tissue, central nervous system, and testis. Because of its different localization and symptoms, and the lack of diagnostic algorithm, MS is a real diagnostic challenge particularly in patients without initial bone marrow involvement. The correct diagnosis of MS is important for optimum therapy, which is often delayed because of a high misdiagnosis rate. We reported three cases of MS derived from spine presented with back pain, paraplegia, paraparesis, respectively, and reviewed the relevant literature.
\end{abstract}

\section{Introduction}

In 1811, myeloid sarcoma (MS) was described for the first time by Burns. Afterward, in 1853, King called the disease chloroma due to its greenish appearance. ${ }^{1} \mathrm{MS}$, also known as granulocytic sarcoma, is an extramedullary tumor composed of mature or immature myeloid blast cells. ${ }^{2}$ According to the World Health Organization, MS is categorized as a subtype of acute myeloid leukemia (AML). ${ }^{3}$ The MS can arise before the diagnosis of intramedullary AML without evidence of blood or bone marrow disease, which is defined as isolated, primary, or nonleukemic MS. ${ }^{4}$ The isolated MS is a rare disease with an incidence of 2 in 1,000,000 adults, ${ }^{5}$ accounting for only $0.7 \%$ of all AML cases. ${ }^{4}$ According to a large study of 746 patients in a national dataset, ${ }^{6}$ isolated MS may develop at any anatomical site, and the most common site is the soft tissues (31.3\%). By contrast, only 4.9 to $6.6 \%$ of isolated MS are derived from the bone. ${ }^{4,6}$ Especially, isolated MS involving the spine is extremely rare. Here, we report three cases of MS

DOI https://doi.org/10.1055/s-0041-1742079 ISSN 2278-330X

How to cite this article: Shah $\mathrm{K}$, Panchal $\mathrm{H}$, Patel A, et al. Spine Myeloid Sarcoma: A Case Series with Review of Literature. South Asian J Cancer 2021;10(4):251-254. from spine presented with back pain, paraplegia, paraparesis, respectively, and review the relevant literature. This study was approved by the institutional review board.

\section{Case 1}

A 47-year-old male presented with back pain radiating to right lower limb for the last 6 months. He also complained of anorexia and weight loss of $\sim 5 \mathrm{~kg}$. Physical examinations revealed that mild-to-moderate tenderness on sacral region with a very mild bulging with firm consistency. Blood reports including complete blood count, renal function test, and liver function test were normal.

Computed tomographic (CT) scan of thorax, abdomen, and pelvis showed presence of ill-defined lytic lesion with soft tissue component measures $112 \times 86 \times 155 \mathrm{~mm}$, which involves adjacent paraspinal muscles from L4 to S5 vertebrae on left side ( - Fig. 1A-C). Biopsy of lesion revealed MS on immunohistochemistry. Bone marrow was normocellular

(C) 2021. MedIntel Services Pvt Ltd.

This is an open access article published by Thieme under the terms of the Creative Commons Attribution-NonDerivative-NonCommercial-License, permitting copying and reproduction so long as the original work is given appropriate credit. Contents may not be used for commercial purposes, or adapted, remixed, transformed or built upon. (https://creativecommons.org/licenses/by-nc-nd/4.0/).

Thieme Medical and Scientific Publishers Private Ltd A-12, Second Floor, Sector -2, NOIDA -201301, India 

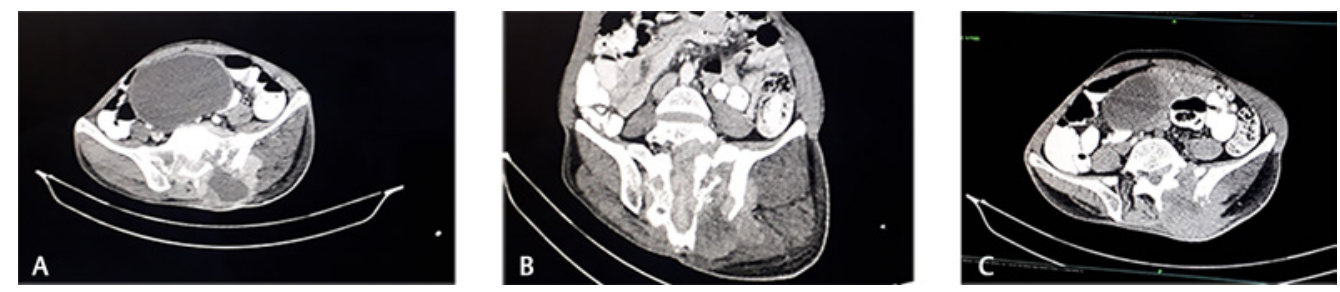

Fig. 1 (A-C) Computed tomographic scan of thorax, abdomen, and pelvis showed presence of ill-defined lytic lesion with soft tissue component measures $112 \times 86 \times 155 \mathrm{~mm}$, which involves adjacent paraspinal muscles from L4 to S5 vertebrae on left side.

with no high-risk cytogenetic ( - Fig. 2A-D). The patient received induction chemotherapy with cytarabine and an anthracycline. The combination is a 5-day continuous infusion of cytarabine at the dosage of $100 \mathrm{mg} / \mathrm{m}^{2}$ per day on days 1 to 5 and daunorubicin at $60 \mathrm{mg} / \mathrm{m}^{2}$ per day on days 1 and 2 due to poor performance status of patient (significant weight loss). During chemotherapy, the symptoms gradually disappeared, and the patient was able to walk without support. Magnetic resonance imaging (MRI) scan revealed that residual shrunken lesion. Later, the patient received four cycles of consolidation chemotherapy with high-dose cytarabine regimen $\left(2 \mathrm{~g} / \mathrm{m}^{2} \mathrm{q} 12 \mathrm{~h}\right.$ on days 1,3 , and 5$)$ followed by local radiation therapy.

\section{Case 2}

A 24-year-old male presented with inability to move both lower limbs for the last 15 days. Physical examination revealed paraplegia with loss of sensation in both lower limbs. Blood reports showed hemoglobin of $7.8 \mathrm{~g} / \mathrm{dL}$, white blood cell of 102.4103 cells $/ \mu \mathrm{L}$, platelet of 540103 cells $/ \mu \mathrm{L}$. MR DL spine showed altered marrow signal intensity lesion involving D4 -D7 vertebral body. Bone marrow was hypercellular marrow consistent with chronic myeloid leukemia chronic phase (CML-CP). The Philadelphia chromosome (translocation 9; 22)
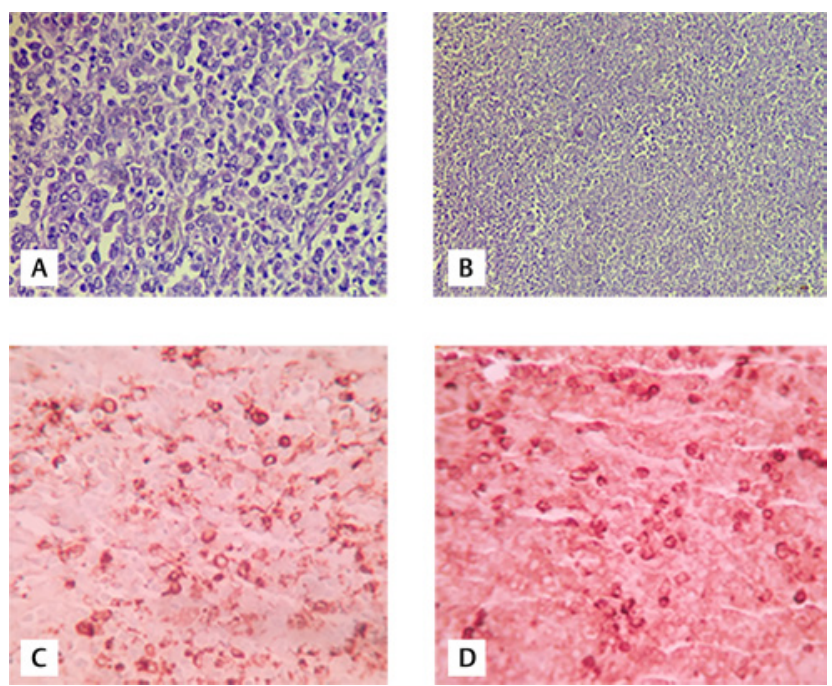

Fig. 2 (A and B) High-power view shows round cells with vesicular nucleoli, small nucleoli, and scanty cytoplasm; few eosinophilic precursors are also seen and lower-power view showing diffuse infiltration by small-to-medium round cells. (C, D) MPO immunohistochemistry stain positive and CD 13 stain positive. was present on karyotype and fish $(9,22)$ positive for BCRABL fusion. The patient treated with D4-D7 laminectomy surgery followed by radiation of 15 fractions with total dose of 30GY. Imatinib $400 \mathrm{mg}$ was started and patient was monitored regularly on outpatient department basis.

\section{Case 3}

A 32-year-old female presented with bilateral lower limb weakness for the last 2 months. Physical examinations revealed paraparesis. Blood reports including complete blood count, renal function test, and liver function test were normal. MR DL spine showed altered marrow signal intensity lesion involving D6-D8 vertebral body. Bone marrow was normocellular with no high-risk cytogenetic. Patient treated with $7+3$ induction chemotherapy combination is a 7-day continuous infusion of cytarabine at the dosage of $100 \mathrm{mg} / \mathrm{m}^{2}$ per day on days 1 to 7 and daunorubicin at $60 \mathrm{mg} / \mathrm{m}^{2}$ per day on days 1 to 3 . Then patient operated with D6-D8 laminectomy followed by local radiation therapy 15 fractions with total dose of $30 \mathrm{GY}$ and achieved positron emission tomography-computed tomography complete remission. The patient received four cycles of consolidation chemotherapy with high-dose cytarabine regimen $\left(2 \mathrm{~g} / \mathrm{m}^{2} \mathrm{q} 12 \mathrm{~h}\right.$ on days 1,3 , and 5$)$ ( - Tables 1 and 2 ).

At the 24-month follow-up, three patients reported complete relief of back pain and lower limb weakness. X-rays showed that the overall spine alignment was intact and there was no evidence of a recurrent lesion. MRI showed no evidence of compressive or remnant lesion.

\section{Discussion}

MS is classified according to the predominant cell type (blastic, monoblastic, and myelomonocytic). ${ }^{7}$ MS can have different clinical presentations. MS can appear simultaneously with AML. Isolated MS involving the spine is extremely rare. Isolated MS involving the spine is associated with or without bone involvement or bone destruction. ${ }^{8}$ Isolated MS can be manifested with various symptoms depending on the tumor size and primary tissue/organ, which makes the diagnosis challenging. It has been reported that up to $47 \%$ of MS cases are misdiagnosed. ${ }^{9}$ Movassaghian et al have analyzed 345 cases of isolated MS in the survival, epidemiology, and end results database, and demonstrated that there are only four cases of isolated MS involving vertebral column $(1.17 \%, 4 / 339)$ and two cases involving spinal cord $(0.59 \%$, 2/339). ${ }^{3}$ Our comprehensive literature search found that 
Table 1 Demographic and clinical features

\begin{tabular}{|c|l|l|l|l|}
\hline Sl. no. & $\begin{array}{l}\text { Age } \\
\text { (year)/ sex }\end{array}$ & Presentation & Physical examination & Systemic examination \\
\hline 1 & $47 / \mathrm{M}$ & $\begin{array}{l}\text { Back pain radiating to right lower limb, } \\
\text { anorexia and weight loss of } \sim 5 \mathrm{~kg} \text { for the } \\
\text { last } 6 \text { months }\end{array}$ & $\begin{array}{l}\text { Tenderness on sacral region with } \\
\text { a very mild bulging with firm } \\
\text { consistency }\end{array}$ & No hepatosplenomegaly \\
\hline 2 & $22 / \mathrm{M}$ & $\begin{array}{l}\text { Bilateral lower limb weakness and low- } \\
\text { grade fever for the last 15 days }\end{array}$ & Paraplegia & Hepatosplenomegaly \\
\hline 3 & $25 / \mathrm{F}$ & $\begin{array}{l}\text { Bilateral lower limb weakness for the last } \\
2 \text { months }\end{array}$ & Paraparesis & No hepatosplenomegaly \\
\hline
\end{tabular}

Table 2 Histopathology, immunohistochemistry, imaging, and treatment

\begin{tabular}{|c|c|c|c|c|c|}
\hline SI. no & $\begin{array}{l}\text { Bone marrow } \\
\text { aspiration and } \\
\text { biopsy }\end{array}$ & $\begin{array}{l}\text { Biopsy with } \\
\text { immunohistochemistry }\end{array}$ & $\begin{array}{l}\text { CD marker } \\
\text { positive }\end{array}$ & Imaging & Treatment \\
\hline 1 & $\begin{array}{l}\text { Normocellular } \\
\text { bone marrow }\end{array}$ & $\begin{array}{l}\text { L4 to } \$ 5 \text { vertebrae lesion biopsy } \\
\text { s/o diffuse infiltration of small } \\
\text { primitive cells among the } \\
\text { trabecular bone. Sections shows } \\
\text { high-grade malignant neoplasm } \\
\text { comprising of sheets of rounded } \\
\text { malignant cells with moder- } \\
\text { ate eosinophilic cytoplasm, } \\
\text { central to eccentric nuclear with } \\
\text { prominent nucleoli, background } \\
\text { eosinophils, extensive necrosis } \\
\text { and apoptosis }\end{array}$ & $\begin{array}{l}\text { Myeloperoxidase } \\
\text { (MPO), CD30, } \\
\text { LCA) and CD13 }\end{array}$ & $\begin{array}{l}\text { Computed tomo- } \\
\text { graphic }(C T) \text { scan } \\
\text { of thorax, abdomen } \\
\text { and pelvis showed } \\
\text { presence of ill-de- } \\
\text { fined lytic lesion and } \\
\text { soft tissue com- } \\
\text { ponent measures } \\
112 \times 86 \times 155 \\
\text { mm, which involves } \\
\text { L4 to S5 vertebrae on } \\
\text { left side }\end{array}$ & $\begin{array}{l}\text { Cytarabine } 100 \mathrm{mg} / \\
\mathrm{m}^{2} / \text { day for } 5 \text { days } \\
\text { and daunorubicin at } \\
60 \mathrm{mg} / \mathrm{m}^{2} / \text { day for } 2 \\
\text { days } \mathrm{f} / \mathrm{b} \text { consolida- } \\
\text { tion chemotherapy } \\
\text { and radiation }\end{array}$ \\
\hline 2 & $\begin{array}{l}\text { Hypercellular mar- } \\
\text { row consistent with } \\
\text { chronic myeloid } \\
\text { leukemia chronic } \\
\text { phase (CML-CP) }\end{array}$ & $\begin{array}{l}\text { D4-D7 vertebrae lesion biopsy } \\
\text { s/o malignant round cell tumor } \\
\text { infiltrating bone and soft tissue }\end{array}$ & $\begin{array}{l}\text { LCA, } \\
\text { CD43, } \\
\text { CKit (CD 117), } \\
\text { CD68, MIB1- } \\
60-70 \%\end{array}$ & $\begin{array}{l}\text { MR DL spine altered } \\
\text { marrow signal inten- } \\
\text { sity lesion involving } \\
\text { D4-7 vertebral body }\end{array}$ & $\begin{array}{l}\text { D4-D7 laminectomy } \\
\text { followed by radiation } \\
\text { with imatinib } 400 \\
\text { mg daily }\end{array}$ \\
\hline 3 & $\begin{array}{l}\text { Normocellular } \\
\text { bone marrow }\end{array}$ & $\begin{array}{l}\text { D6-D8 vertebrae lesion biopsy } \\
\text { s/o malignant round cell tumor } \\
\text { infiltrating bone and soft tissue }\end{array}$ & $\begin{array}{l}\text { LCA, } \\
\text { MPO, } \\
\text { vimentin, } \\
\text { CD99, } \\
\text { desmin, } \\
\text { CD68 }\end{array}$ & $\begin{array}{l}\text { MR DL spine altered } \\
\text { marrow signal inten- } \\
\text { sity lesion involving } \\
\text { D6-8 vertebral body }\end{array}$ & $\begin{array}{l}7+3 \text { induction } \\
\text { chemotherapy } \\
\text { D6-D8 laminec- } \\
\text { tomy followed by } \\
\text { radiation followed } \\
\text { by consolidation } \\
\text { chemotherapy }\end{array}$ \\
\hline
\end{tabular}

only eight cases of isolated MS involving the spine have been reported thus far. ${ }^{8,10-14}$

Histological examination is crucial for MS diagnosis. The histological characteristics can vary for MS diagnosis according to the degree of myeloid differentiation. Typically, MS consists of myeloblasts and granulocytic cells, and the enlarged neoplastic cells. ${ }^{15,16}$ If developed concurrently with AML, the cell lineage of MS would be similar to leukemia. In addition to hematoxylin and eosin staining, immune histochemical analysis is the most important method for the diagnosis of MS. The markers of MS include CD4, CD30, CD34, CD56, CD61, CD68, CD99, CD117, MPO, lysozyme, CD68-KP1, TdT, and glycophorin A. ${ }^{17,18}$ Intracellular staining of MPO is an effective method for the diagnosis of MS and differential diagnosis from other tumors. ${ }^{19}$ Notably, MPO may be not expressed in some monocytic or poorly differentiated MS. ${ }^{20}$ The markers MPO, CD3, CD20, and CD79A should be used for differential diagnosis. In our patient, the MS cells expressed MPO, CD30, and CD117 but did not express CD34, CD3, and CD20, making the diagnosis straightforward without evidence of leukemia or clinical history.
It has been shown that patients with MS involving the bone or nerve system have a short 6 months overall survival as compared with those involving other sites. ${ }^{5}$ Currently, there is no consensus on the optimal treatment for isolated MS. ${ }^{21}$ Nearly half of isolated MS will develop into medullary AML within $\sim 5$ to 11 months after the diagnosis of MS. ${ }^{22}$ The induction chemotherapy regimen is usually the same as that of medullary AML. ${ }^{23}$ Alternatively, surgical resection or local radiotherapy could be used for induction. Nevertheless, these treatments cannot delay disease progression. ${ }^{24}$ The systemic cytarabine-based chemotherapy can retard disease progression and improve the overall survival as compared with local therapy. ${ }^{25}$ Chemotherapy is the most common treatment for isolated MS involving the spine. In our two patients, an AML-type regimen was used for induction chemotherapy, and the patient responded well. After one cycle of treatment, all the symptoms disappeared and the mass size was significantly reduced. Without standardized chemotherapy and radiotherapy, the patient is likely to die within a couple of months after the disease onset, even without evidence of progression to AML. In addition to chemotherapy and 
radiotherapy, allogeneic hematopoietic cell transplantation (HCT) is also used to treat isolated MS. It has been shown that patients with isolated or leukemic MS receiving allergenic HCT had longer median survival time. ${ }^{26}$ Widhalm et al have reported that in an isolated MS case involving brain and spinal cord, the patient receiving combined treatment of radiotherapy, chemotherapy, and allogeneic bone marrow transplant had a disease-free survival of 7 years. ${ }^{13} \mathrm{MS}$ as the initial presentation of CML-CP may be a unique subset of CML and the prognosis is unclear due to the rarity of the disease. However, considering that the treatment of MS is based on chemotherapeutic protocols of underlying leukemia, the prognosis of our case is expected to be better since the CML-CP is well controlled with only imatinib treatment. Further, in the tyrosine kinase inhibitors era, the overall survival of CML in the medullary blast phase, as well as CML patients with MS, has improved. ${ }^{27}$ Despite the rarity of the disease and diagnostic difficulty for clinician, MS can be correctly diagnosed with strong clinical suspicion and adequate panels of immunohistochemical stains. The bone marrow aspiration, cytogenetic study, and molecular analysis are also mandatory for the synchronous AML or CML. Systemic chemotherapy should be administrated shortly once the diagnosis confirmed. A local treatment for MS such as radiation therapy or surgical resection has been found less effective than chemotherapy at improving the disease-free interval. Since its pathogenesis and genomic landscape are not well understood, the prognosis remains dismal, even in the novel agent era.

\section{Conclusion}

In conclusion, isolated MS is a rare and unique entity of myeloid neoplasm. Therefore, each case description is fundamental to provide a better knowledge about this rare malignancy. Further prospective studies are necessary for stratification of the role of chromosome and genetic abnormality and the treatment outcomes. To fully understand the characteristics of isolated MS, a larger number of patients in a multinational study are necessary to identify novel and selected treatments.

\section{Conflicts of Interest}

The authors declare that they have no conflicts of interest

\section{References}

1 Seok JH, Park J, Kim SK, et al. Granulocytic sarcoma of the spine: MRI and clinical review. AJR Am J Roentgenol 2010; 194(2):485-489

2 Almond LM, Charalampakis M, Ford SJ, et al. Myeloid sarcoma: presentation, diagnosis, and treatment. Clin Lymphoma Myeloma Leuk 2017;17(5):263-267

3 Arber DA, Orazi A, Hasserjian R, et al. The 2016 revision to the World Health Organization classification of myeloid neoplasmsandacuteleukemia.Blood2016;127(20):2391-2405

4 Movassaghian M, Brunner AM, Blonquist TM, et al. Presentation and outcomes among patients with isolated myeloid sarcoma: a Surveillance, Epidemiology, and End Results database analysis. Leuk Lymphoma 2015;56(6):1698-1703
5 Yilmaz AF, Saydam G, Sahin F, et al. Granulocytic sarcoma: a systematic review. Am J Blood Res 2013;3(4):265-270

6 Goyal G, Bartley AC, Al-Kali A, et al. Clinical features and outcomes of isolated myeloid sarcoma in the United States: analysis using a national dataset. Blood 2016;128:1618

7 Pileri SA, Ascani S, Cox MC, et al. Myeloid sarcoma: clinicopathologic, phenotypic and cytogenetic analysis of 92 adult patients. Leukemia 2007;21(2):340-350

8 Serefhanoglu S, Goker H, Aksu S, et al. Spinal myeloid sarcoma in two non-leukemic patients. Intern Med 2010; 49(22):2493-2497

9 Yamauchi K, Yasuda M. Comparison in treatments of nonleukemic granulocytic sarcoma: report of two cases and a review of 72 cases in the literature. Cancer 2002;94(6):1739-1746

10 Yang C, Fang J, Xu Y. Isolated spinal myeloid sarcoma with rapid progression. Spine J 2016;16(8):e517-e518

11 Lim SH, Nam HN, Lim KI, et al. A case of myeloid sarcoma presenting with an orbital mass, hearing loss, and multiple cranial neuropathies. Turk J Pediatr 2018;60(3):322-325

12 Qian J, Cui QU, Liu Y, et al. Isolated primary intracranial myeloid sarcoma with neuromeningeal infiltration: a case report. Oncol Lett 2015;9(4):1647-1650

13 Widhalm G, Dietrich W, Müllauer L, et al. Myeloid sarcoma with multiple lesions of the central nervous system in a patient without leukemia. Case report. J Neurosurg 2006;105(6):916-919

14 Yang B, Yang C, Fang J, et al. Clinicoradiological characteristics, management and prognosis of primary myeloid sarcoma of the central nervous system: a report of four cases. Oncol Lett 2017;14(3):3825-3831

15 Djurdjevic P, Jovanovic D, Antic D. Isolated myeloid sarcoma of the neck and chest: differential diagnosis and therapeutic approach. Open Med (Wars 2014;10(1):34-38

16 Hagen PA, Singh C, Hart M, et al. Differential diagnosis of isolated myeloid sarcoma: a case report and review of the literature. Hematol Rep 2015;7(2):5709

17 Magdy M, Abdel Karim N, Eldessouki I, et al. Myeloid sarcoma. Oncol Res Treat 2019;42(4):224-229

18 Shahin OA, Ravandi F. Myeloid sarcoma. Curr Opin Hematol 2020;27(2):88-94

19 Bakst RL, Tallman MS, Douer D, et al. How I treat extramedullary acute myeloid leukemia. Blood 2011;118(14):3785-3793

20 Papamanthos MK, Kolokotronis AE, Skulakis HE, et al. Acute myeloid leukaemia diagnosed by intra-oral myeloid sarcoma. A case report. Head Neck Pathol 2010;4(2):132-135

21 Solh M, Solomon S, Morris L, et al. Extramedullary acute myelogenous leukemia. Blood Rev 2016;30(5):333-339

22 Chevallier P, Mohty M, Lioure B, et al. Allogeneic hematopoietic stem-cell transplantation for myeloid sarcoma: a retrospective study from the SFGM-TC. J Clin Oncol 2008;26(30):4940-4943

23 Paydas S, Zorludemir S, Ergin M. Granulocytic sarcoma: 32 cases and review of the literature. Leuk Lymphoma 2006; 47(12):2527-2541

24 He J, Zhu L, Ye X, et al. Clinical characteristics and prognosis of nonleukemic myeloid sarcoma. Am J Med Sci 2014;347 (6):434-438

25 Imrie KR, Kovacs MJ, Selby D, et al. Isolated chloroma: the effect of early antileukemic therapy. Ann Intern Med 1995; 123(5):351-353

26 Al-Khateeb H, Badheeb A, Haddad H, et al. Myeloid sarcoma: clinicopathologic, cytogenetic, and outcome analysis of 21 adult patients. Leukemia Res Treat 2011;2011:523168

27 Chen Z, Wang W, Rich A, et al. Myeloid sarcoma as the initial presentation of chronic myelogenous leukemia, medullary chronic phase in era of tyrosine kinase inhibitors: a report of 11 cases. Am J Hematol 2015;90(8):E146-E148 